\title{
Market Discipline and Bank Risk-Taking: The Interbank Deposit Perspective
}

\author{
Rugangira Paul Kato \\ Department of Banking and Financial Services, Institute of Finance Management, Dar es Salaam, Tanzania \\ Email:katokaab@gmail.com
}

How to cite this paper: Kato, R. P. (2021). Market Discipline and Bank Risk-Taking: The Interbank Deposit Perspective. Journal of Financial Risk Management, 10, 54-79. https://doi.org/10.4236/jfrm.2021.101004

Received: December 17, 2020

Accepted: March 20, 2021

Published: March 23, 2021

Copyright ( 2021 by author(s) and Scientific Research Publishing Inc. This work is licensed under the Creative Commons Attribution International License (CC BY 4.0).

http://creativecommons.org/licenses/by/4.0/

\begin{abstract}
This paper investigates the relation between market discipline and bank risk-taking for Tanzanian commercial banks during the period 2009-2017. In the fixed effect (within) estimator, it uncovers mixed results. It found some support that market discipline exists and via interbank deposit reduced bank risk (i.e. credit risk). Contrary to expectation, the finding exhibits that the link between the interaction of market discipline and bank capital on bank risk is negative and statistically significant. It is also evident that bank capital, off-balance items, and size better explain the variation in bank risk. The results serve as a policy hint to banks' regulators and policymakers in strengthening market discipline framework for the reduction of bank risk-taking.
\end{abstract}

\section{Keywords}

Market Discipline, Risk-Taking, Commercial Banks

\section{Introduction}

As the world becomes more complex and competitive, market discipline in mitigating bank risk-taking is hotly debated in the academic environment and policymakers today (Fosu et al., 2017; Hoang et al., 2014). Market discipline constitutes a form of self-regulation exercised by purchasers of financial services which is meant to punish the behavior of sellers that impose a cost on the buyers for which they have not been compensated (Berger, 1991). Regardless of the fundamental role of the banking industry in the socio-economic development, the industry is exposed to a spectrum of risk. The inherent risks can have adverse impact on banks' cash flows, profitability and capital, which in turn, could pose threat to the whole banking sector. A central argument is that if market discipline governance works well as the traditional prudential regulations used to do, there will be high likelihood of disproportionate bank risk-taking to fall. A 
bag of academic research on the association between market discipline and bank risk-taking looks at well-informed financial investors, and ignores the important group, small depositors (Arnold et al., 2016). In addition, few of these disentangle between interbank deposits and issued subordinated debt as measurement of market discipline. This study, therefore, investigates empirically whether market discipline exists to curb high risk taking in Tanzanian commercial banks. This is new. The research agenda is important for Tanzania, given the banking system structure which is concentrated and featured by small privately owned commercial banks ${ }^{1}$, at relatively nascent stage of development. These structural features underline financial stability challenges were notable with asset quality deterioration, cash flows pressure, undercapitalization, and credit growth reduction.

More specifically, the underlying issues are three. One, Tanzania banking industry undoubtedly faced a tough year in 2013, driven by the need for greater provisioning in deteriorating credit risk environment (Eastern African Banking Sector, 2013). The adverse consequences of the bad loans impacted the banking sector's return on average equity, which trended sharply down from $18.44 \%$ (2009) to $5.12 \%$ (2017). Two, banks in Tanzania are renowned for paying the lowest deposit rates in the Eastern Africa Banking Sector relative to its counterparty countries (i.e. Kenya, Uganda, and Rwanda). Hence, signaling that their depositors may have low sensitivity to discipline banks for their aggressive risk behavior. Finally, to manage its cash flows revenue, in January, 2016, government entities were directed to transfer billions of shillings held by commercial banks to the Bank of Tanzania (BOT). In short term perspective, the regulatory directive ended into banks' liquidity pressure, loss in substantial amount of deposits, as well the disruption of the interbank funding volume transactions.

Moreover, in the 1990s, Tanzanian banking industry faced profound deregulated market environment in terms of product diversification and relaxation of banks' entry restrictions. This provision is asserted in The Banking and Financial Institution Act (BFIA) provided guidance in 1990 and updated in 2008. It is worth noting however, that as the tendency of banks to take excessive risk heightened, a range of regulations was revoked and replaced by BFIA (2014). Subsequent to these developments and challenges, the efficacy of prudential regulations in restraining safety and stronger of the financial systems has cast doubts. It should, therefore, be argued that relying solely on prudential regulations is not enough to redress bank risk-taking. In recognizing these facts, the examination of the aforementioned question appears pertinent and timely. Incidentally, many designed proposals had been advocating the application of market discipline conventional regulatory in monitoring and controlling bank risk. The usefulness of market discipline in mitigating bank risk-taking and moral hazard problems is also highlighted in both Basel II Pillar 3 and in the enduring architecture initiatives towards Basel III.

However, the presence of mispriced deposit insurance premium, limited lia-

${ }^{1}$ As at November, 2018, 29 majority foreign-owned banks and 18 domestic banks hold $92 \%$ banking assets. 
bility, regulatory compliance, too big to fail (TBTF) and other safety net tend to intensify moral hazard and asymmetric information problems (Galai \& Masulis, 1976; Jensen \& Meckling, 1976). This, in turn, encourages greater incentive to bank risk-taking behaviour if market discipline strength is not strong. With this position, bank shareholders/management may use customers' deposits to pursue risky policies that enhance their benefits at the expense of dispersed and unsophiscated (average) bank depositors, other creditors and deposit insurance funds. This hints that these aggressive actions should be monitored properly in order to reduce the possibility of banks' collapses and failures.

To avoid banks engaging in moral hazard behaviour of borrowing deposit at or below the risk free rate and investing the funds in risky assets at higher expected yield, risk exposed private investors discipline banks. They do that by demanding higher yield spreads (rewards) on their deposit portfolios and withdrawing their funds (Martinez Peria \& Schmukler, 2001; Nier \& Baumann, 2006). The properly priced deposit rates and deposits withdrawals raise banks' costs of financing and decreases interest income and the same implication is true for net interest margin. In effect, banks are disciplined and if market discipline tools effectively control banks-it will lead to healthier banking firms and the stable financial system as a whole. Market discipline tools may include subordinated notes and debentures (SNDs) spread or yield, uncovered funding by explicit deposit insurance scheme (i.e. interbank deposits), interest rates on deposits or certificate of deposits, deposits growth, market concentration and information disclosure. By appealing to market discipline, the deterioration on these indicators is a warning to an increase in the banks' risk profile. Such signal calls for prompt remedial measures to be taken.

Therefore, this study employed the interbank deposits to examine whether market discipline exists and works in reducing Tanzanian commecrial banks' risk-taking attitude. The usage of interbank deposits is chosen to capture market discipline because of underdeveloped SND debt market in Tanzania. Additionally, SNDs are infrequent and not a mandatory issuance instruments requirement by commercial banks in the country. Yet, Furfine (2001) advocates that interbank deposits offer the strongest disciplinary impact as investors in this debt instruments are more sophisticated than average depositors. In this case, if premiums for insured bank deposits reflect default risk, then the market is partially disciplining banks (Gorton \& Santomero, 1990). The sub-debt instruments issuance is widespread and a mandatory in US, UK and European banking industries (see, for example, Sironi, 2003; Zhang et al., 2014). Institutional investors are the main and largely debt holders of SNDs. Because of the substantial amount invested, they have more incentive in monitoring and disciplining banks' behaviours, though arguably would lessen the magnitude of risk-taking.

The interbank deposits are traded in the interbank money market-a market in which individual banks execute their trading deals with a view to bridge their demand for and supply of short funding. As an investor in the interbank market, 
the lending bank faces distress to both risk and return similar to the borrowing bank (Nier \& Baumann, 2006). Thus, a fluctuation in the interbank deposit will imply to that lending bank is likely to be sensitive to the extent on borrowing bank risk taking. Following Nier \& Baumann (2006) and Hoang et al. (2014) work, the baseline hypothesis tested is that bank's risk should be decreasing in the market discipline. To test the risk-market discipline relation, 32 Tanzanian commercial banks database is constructed over the period 2009-2017. It contains risk measures, market discipline, bank balance sheet characteristics, control variables and year dummies.

The current paper contributes to the literature in three distinct ways: First, it offers better insight for market discipline by understanding the relationship between market discipline and bank risk-taking through interbank deposits in Tanzania. To the best of my knowledge, there is no study that looks at this connection as an illustrative case in Tanzania banking industry. Few empirical extant studies examine market discipline and bank risk-taking relation (Fazelina Sahul \& Norhanishah Mohd, 2017; Hoang et al., 2014; Nier \& Baumann, 2006). By and large, the previous empirical literature had devoted considerable attention to the influence of bank balance sheet specific risk on market discipline in developed countries because of their well-developed capital markets. Second, it tests the theoretical research grounded by Gorton \& Santomero (1990) who analyses market discipline through bank subordinated debt yield spreads on the balance sheet risk measures convex relation. Flannery \& Sorescu (1996) and Hoang et al. (2014) had examined the hypothesis. The authors found unsupported nonlinear relation between market discipline and bank risk. Finally, the results have vital policy implication in regard to banking traditional prudential regulations. It is worth mentioning that SNDs issuance as part of capital should be mandatory to the large Tanzanian commercial banks. The SNDs debt instrument will complement interbank deposit in enhancing market discipline credibility to reduce excessive bank risk. Besides, any movement in the SND yield spread will save as an information warning flag for prompt remedial actions by bank regulatory authorities, hence, attenuating banking system stability risks.

The primary empirical evidence in this paper is as follows: Market discipline reduced bank risk through credit risk. It is statistically insignificant in both liquidity risk and insolvency risk. The link between the interaction of market discipline and bank capital on bank risk (insolvency risk) is negative and statistically significant. By constraining capital, coefficient estimate on market discipline, market discipline is positive with $\mathrm{z}$-score, suggesting the convergence to market discipline hypothesis. The nonlinear association between market discipline and bank risk is not displayed. Finally, some bank characteristics better explain the variation in bank risk.

The remainder of the article proceeds as follows. Section 2 surveys the relevant literature and develops hypotheses. Data and methodology are reported in Section 3. Sections 4 and 5 discuss empirical results and robustness checks, re- 
spectively. The final section concludes the study.

\section{Literature Review and Hypotheses Development}

Prior market discipline empirical literature shows that prediction on the relationship between market discipline and risk-taking in banks remains unambiguous. Hence, this section presents a theoretical lens in order to understand the underlying association and develop the hypotheses. The primary question is whether the finding is unique to Tanzanian commercial banks.

The theoretical foundation of market discipline holds that uninsured deposit debt-holders (i.e. private investors) discipline banks and take actions to protect themselves from greater risk-taking. The theory predicts that if bank owners and creditors have greater exposure to losses when their banks fail, they will limit the risk assumed by their banks (Gilbert, 1990). The liability debt-holders use varying punishment actions to limit bank managers pursuing excessive risk-taking behaviours-that eventually impair shareholders' wealth. These mechanisms range from the demand for higher risk premium on deposits, smaller quantity of uninsured deposits attraction, funds withdrawal, moving part of deposits to safer banks, to converting uninsured deposits into insured ones (Martinez Peria \& Schmukler, 2001; Park \& Peristiani, 1998). Taken as a whole, these actions are intended to reduce depositors' funds at risk exposure. More generally, the actions can be categorized into two forms, namely price and quantity based depositor market discipline mechanisms. Whilst the price based approach is associated with uninsured depositors demanding higher risk premium, the quantity based mechanism concentrates on the remaining actions. Market discipline is important in banks as it mitigates purchasers of financial services to pursue moral hazard behaviours that are detrimental to uninsured depositors. indeed, Calomiris \& Jaremski (2019) argue that extant empirical literature proposes that moral hazard costs of deposit insurance have out-weighed its liquidity reduction benefits.

Earlier theoretical and empirical literatures look at the effectiveness of market discipline in monitoring banks in US banking industry. Specifically, they focus on analysing market discipline responsiveness to bank specific risks. Clearly, the produced evidence is patchy conclusions. One branch of the literature analyzes market discipline from default risk premium. It documents statistically significant relationship between market discipline and deposit interest rates in US bank holding companies (Baer \& Brewer, 1986), US banks (Hannan \& Hanweck, 1988), Argentine, Chilean, and Mexican banking sectors (Martinez Peria \& Schmukler, 2001), and publically bank cross-country data (Semenova, 2012). In addition, the deposit growth rates (Goldberg \& Hudgins, 2002; Martinez Peria \& Schmukler, 2001) decreased in greater bank risk-taking. Empirical evidence by Bennett et al., (2015) indicate that market discipline decreased deposit volume and increased deposit interest rates in unique data set of losses rates expected by Federal Depost Insurance Corporation on creditors at banks that failed between 
2008 and 2010. In addition, the authors document that liability debt-holders monitor their banks behaviour and reallocate their portfolios investment in ways that protect them from incurring losses. The authors contend that the decline in quantity deposit shares and increase in default risk premium on uninsured deposits are the test and supporting the existence of market discipline. Bertay et al., (2013) provide strong impact of market discipline on banks' interest expense and deposit growth rate. Specifically, they show that the coefficient on the interaction term of equity and liabilities over GDP (a proxy of bank risk) is negative on bank's interest expense. Analogous result is indicated in the interaction term of liquidity and liabilities over GDP. The findings on these research papers are consistent with existence of market discipline. Conversely, Arnold et al., (2016) find that savers in German are patient with troubled banks as they are not quick to withdraw part of their savings invested deposit and charge higher risk premia. They interpreted patience as absence of market discipline in German banks.

The second vast stream empirical studies evaluate market discipline around the default risk sensitivity of SNDs yield spreads to balance sheet risks. The primary insight of this research is that SNDs yields information do reflect the issuing banks' risk—taking (Flannery \& Sorescu, 1996; Goyal, 2005; Gropp \& Moerman, 2004; Sironi, 2003; Zhang et al., 2014). Contrastingly, other findings show weak or fail to establish association between risk premia and subordinated notes and debentures yields. For instance, using Brazilian banking sector sample in a dynamic panel data, De Mendonca \& Loures (2009) find weak connection between credit risk and SNDs return, consistent with the argument of incredible and weak market discipline hypothesis. In contrast, Tovar-García (2015) demonstrates that market discipline via subordinated debt is not supported in Mexican banking sector. The author contends that this should be attributed to a consequence of incorrect signals from the regulatory bodies, weak institutional framework, and undeveloped financial market. However, in US bank holding companiess, Balasubramnian \& Cyree (2011) indicate that the SNDs yield spread sensitivity to conventional firm specific default risk measures declined following LTCM bailout and trust-preferred securities issuance (TPS). They asserted that TPS offers further source of market discipline. Overall, findings from the link between bank specific risk measures and default risk premia paint varied picture.

\section{Previous Literature on Market Discipline and Bank Risk-Taking}

Literature that recognizes the influence of market discipline from the standpoint of prudential risk management behaviour in banks is little, and there remains a lack of agreement. Therefore, the understanding whether or not market discipline is the determinant and induces bank risk-taking is largely perceived a gap that has attracted the interest of academic research today.

Earlier large studies that examine bank deposit insurance and risk-taking show inconsistent results. Testing a stylized banking model, Gropp \& Vesala 
(2004) show that deposit insurance may reduce moral hazard for insured depositors. The authors document that risk-taking (measured by leverage risk, asset risk and interday volatility of the bank's share price) in European banks with a huge share of uninsured funding deposits is low and generates incentives that led to the increase in intrinsic value. The evidence is in line with the TBTF policy. Applying a difference-in-difference setting, some studies demonstrate that the introduction of deposit insurance schemes reduced the sensitivity of depositors' actions to bank risk-taking as opposed to the pre-establishment periods (Calomiris \& Jaremski, 2019; Karas, Pyle, \& Schoors, 2019; Karas, Pyle, \& Schoors, 2013; Lambert, Noth, \& Schüwer, 2017; Yan, Skully, Avram, \& Vu, 2014). Evidently, these papers report that subsequent to deposit guarantee creation, market discipline effect translates into increases in bank risk-taking behavior. In contemporary empirical evidence, Calomiris \& Jaremski (2019) show that US insured state banks increased their leverage (i.e. lowered the capital to asset ratio), and reduced the proportion of cash holdings. More specifically, insured banks enter cash to assets ratio and capital to assets ratio with negative signs and are significant, reflecting the lending riskiness rise over the deposit insurance installation regime. For similar findings, Kusairi et al. (2018) find that deposit insurance policy aggravated bank managers to pursue higher risk by increasing loan portfolio instead of increasing total deposits in ASEAN countries. Accordingly, this strategy can result into higher returns that reduce additional policy operating costs for the banks.

Contrastingly, some studies explore whether the impact of deposit insurance on bank risk-taking incentives (Enkhbold \& Otgonshar, 2013; Karas et al., 2019). Enkhbold \& Otgonshar (2013) demonstrate that the implementation of deposit insurance stabilized the banking system, but also results banks to pursue excessive risk (i.e. overall default risk, credit risk, and liquidity risk) in Asian countries. In Russia, Karas et al. (2019) indicate evidence that is in line with the presence of a causality chain from deposit insurance to greater risk by way of increased moral hazard and decreased market discipline. By comparison, Brandao-Marques et al. (2018) test the link between bank risk taking and government support, and find strong relationship in international sample of rated banks. The association is pronounced and more statistically significant during the 2009-2010 periods. The change in accounting standards in the Europe in the mid-2000s explained this strong relationship. The results remain qualitatively the same when controlling for deposit insurance in 2003-2004 periods, and is negative in $z$-score. Overall, these studies support the theoretical view that increasing financial safety net to banks tends to reduce market discipline, which, in turn induces bank manager to engage into riskier strategy choices.

Other studies apply capital-risk weighted asset ratios to capture bank risk. For instance, on cross country panel data, Nier \& Baumann (2006) investigate the hypothesis that market discipline is effective in providing incentives for banks to limit their risk of default, by holding capital buffers against adverse outcomes in 
portfolio risk. They find a positive relationship between market discipline (i.e. summation of SNDs and interbank deposits or uninsured liabilities) and capital-risk weighted asset ratios. Their finding implies that the banks' incentives to select higher capital buffer is aimed at minimizing the likelihood to insolvency risk and adverse loan portfolio performance. In Chinese banks, Wu \& Bowe (2010) show that information disclosure and interbank deposit are positive and significantly connected with risk-weighted capital. Their work bears similarities to that of Nier \& Baumann (2006) by suggesting that rated banks hold a higher capital buffer to mitigate unforeseen outcomes. The result is also supportive to view that bank with higher capital ratios are more transparent and publicly disclose more information, and their deposits are largely funded by the interbank deposits. In comparison, Fazelina Sahul \& Norhanishah Mohd (2017) test the effectiveness of market discipline using interbank deposits and information disclosure in enhancing prudential risk management practices among East Asian banking institutions. They report that total capital over risk-weighted assets is positively related to interbank deposit holding. Hence, their finding highlights that only interbank deposit holdings drive market discipline in the regional. For the most recent article on the analysis for the sensitivity of capital-assets ratio to deposit insurance, see, Calomiris \& Jaremski (2019), underscored above.

There is also growing empirical literature that offers better understanding of the determinants of bank risk (equity risk or credit risk) in the context of market discipline, proxied by deposit insurance. Stiroh (2006) shows that lending business and concentration on the wide set of noninterest generating activities (newly reported information about BHCs revenue flow) drive the cross-sectional differences bank risk. This positive link finding highlights that the value of increased transparency in mandated regulatory data as a means to enhance market discipline and reduce opacity of complex financial institutions and risk. Haq \& Heaney (2012) examine a range of bank-characteristics as drivers to equity risk (systematic risk, total risk, interest rate risk, and idiosyncratic risk) and credit risk in European countries financial institutions. Specifically, they document mixed results with uninsured deposits. The authors demonstrate a negative link with systematic risk, and a positive association with idiosyncratic risk and credit risk. They further observe conflicting findings with charter value hypothesis, and show that charter value is positive in bank equity risk yet negative in credit risk. Similarly, Bakkar, Rugemintwari, \& Tarazi (2017) evaluate how bank charter affects risk for a sample of OECD banks. The authors find that ex-ante the global financial crisis charter value positively impacted both individual and systematic risks in large and TBTF banks with high growth strategies through riskier policies. The results on these two papers imply that charter value attributed to higher symmetric risk instead of it disciplining bank manages to restrain excessive risk-taking behaviour.

In a broad sample of financial institutions from G7 nations, Hoang et al. (2014) note that market discipline strongly reduced bank risk, in which, equity risk and credit risk are negatively related to uninsured debt. This is evident in 
the presence of risk-adjusted insurance and during the ex-post global financial crisis period, and not in the presence of bank capital. Equally, Dinger \& Hegen (2009) report nondeposit funding decreases bank risk-taking, suggesting that the marginal effect of opacity is lower for banks that focus on interbank borrowings. Conversely, in US BHCs sample, Fosu et al. (2017) find that the effect of opacity measured by analysts' earnings forecast on risk-taking increases (decreases) with banking competition and some extent the share of non-deposit funding in total funding. Specifically, they uncover that reliance on large interbank deposit funding market makes banks more risky; implying the costs of monitoring role through nondeposit funding outweighs the accrued benefits in stabilizing banks. It is important to note that, for monitoring systematic risks, Tanzanian banks adopted the risk management guideline in 2010. At this height, with strengthened financial regulations and market discipline, arguably there is less likelihood Tanzanian banks' to engage into riskier strategy choices. Based on the preceding stylized facts of the relevant theoretical and empirical literature, the first testable hypothesis is:

H1: There is a decrease in bank risk with market discipline.

With regard to convex, there is no consensus whether the link between market discipline and bank risk is nonlinear. Gorton \& Santomero (1990) point out that studies that failed to detect risk premia were due to employing linear regressions in examining bank risk and default spread. Owing this theoretical snag, authors propose and test the application of nonmonotonic methodology and indicate that the bank specific risk measures yet have little predictive power in explaining yield spread. This implies modest evidence of the meaningful market discipline in SND market. Subsequent to this theoretical foundation, Flannery and Sorescu (1996) establish that subordinated debt default risk premia is nonlinearly related to asset risk and leverage in US banks. While some empirical evidence observes a negative relationship (Fazelina Sahul \& Norhanishah Mohd, 2017; Hoang et al., 2014; Nier \& Baumann, 2006; Fosu et al., 2017) provide positive relationship, and Haq \& Heaney (2012) indicate both positive and negative relation between nondeposit funding and banks risk-taking. The finding in the latter authors suggests a nonlinear relation with U-shaped. Hoang et al. (2014) test this hypothesis and display evidence supporting the convexity between uninsured deposits and bank risk that lacks economic significance. Hence, the highlighted literature indicates that the path to bank risk-taking may either decreases or increase with market discipline intensity. That is, at low level of market discipline banks may select and engage in risky investment portfolio which attract higher default risk premium, the reverse is obviously true for banks to choose less risky portfolio at a strong level of market discipline. Based on the aforementioned facts, the relation between bank risk and market risk may not be of linear nature, leading to the second hypothesis as:

$\mathrm{H} 2$ : There is nonlinear relationship in bank risk with market discipline.

Finally, the risk-based capital regulatory indicator is the ongoing debate by 
regulators, policymakers and academicians. To avoid insolvency risk, banks hold capital buffers against adverse outcomes in their investment in risky loans portfolio (Nier \& Baumann, 2006). The theoretical ground of capital-risk relation is moral hazard, which was developed from the existence of agent-principal relationship between shareholders and debtholders in leveraged firm (Jensen \& Meckling, 1976). When deposit insurance is in place, moral hazard problem emergency can contribute banks taking excessive risk. Subsequently, with higher capital levels, this strategy induces banks to select asset risk portfolios that may lead to an increase in shareholders' wealth. Higher capital holdings is planned to absorb unexpected losses and limit moral hazard behaviour in banks (Fungáčová et al., 2014; Milne, 2002). Empirically, Galloway et al. (1997), Kwan \& Eisenbeis (1997), Konishi \& Yasuda (2004), Anginer et al. (2018) show negative relation between risk and bank capital. Testing the interaction of market discipline and bank capital Hoang et al. (2014) show a decrease in risk (i.e. total risk, idiosyncratic risk, and credit risk) on this relation. Overall, this set of empirical evidence documents that bank capital is associated with a reduction in bank risk-taking. In a recent study, Anginer et al. (2018) suggest that bank capital can act as a substitute for weak institutional environment, poor information availability and less efficient oversight by private and public agents in containing systematic fragility. In this regard, higher bank capital positively intensifies financial systematic stability in a country.

In a theoretical perspective, Koehn \& Santomero (1980) argued that greater capitalization levels can induce bank to choose risky assets portfolio in order to compensate for the loss of utility driven by tight capital regulatory intent. Empirically, Klomp \& Haan (2012) and Lotto (2016) displays a positive relationship between bank capital and bank risk in OECD countries and Tanzania, respectively. The insight of a positive direction is that as bank risk increases, managers enhance capital position in line with capital adequacy regulation requirement. In this setting, Lotto (2016) does not consider and test market discipline on bank risk. Tanzanian banks' capital requirements are adequate and exceed the Basel minimum standards. In this regard, it is evident that high nonperforming loans built resilient shock to well-capitalized Tanzanian banks, calling for quality of market discipline to complement the doubtedness in the effectiveness of financial prudential regulations. Accordingly, findings on the link between market discipline and risk in the presence of bank capital offer unappreciable evidence and remain an empirical question. Based on the heightened above discussion and arguments, the third formulated hypothesis is:

H3: There is a decrease in bank risk with market discipline in response to bank holding larger capital buffer.

\section{Data and Methodology}

To test whether market discipline exists and reduces greater risk-taking, this study used bank-level information from Tanzanian commercial banks' annual 
reports and consolidated financial statements, from 2009 to 2017. The motivation for choosing this period is that, the banks were at the height of deterioration in their loan portfolios, which in turn, decreased the magnitude of returns on shareholders' wealth. Subsequent to this trend, over this period investigated, a number of foreign-owned, domestic and community banks either failed, or were placed under compulsory liquidation. Moreover, the announcement by Barlclays Plc (LSE: BARC) to merge Barclays Bank of Tanzania and the National Bank of Commerce Tanzania (NBC), precipitate the matter. The Bank of Tanzania (BOT) website displays data on 37 commercial banks as at the end of December, 2017. From this population some banks are eliminated for the following reason(s): revoked licenses (1), under statutory management of the BOT (1), inadequate bank level accounting data (3), and banks licensed and have less spanning duration of 3 years (-). This setting leaves into a sample of 32 commercial banks in unbalanced panel data.

\subsection{Dynamic Panel Data Methodology}

The dependent variable is bank risk. It is quantified by three measures frequently used in the prior literature. The first proxy is credit risk defined as loan loss provision over total loans, LLPTL. It had been used by Haq \& Heaney (2012), Klomp \& Haan (2012) and Hoang et al. (2014) to predict the determinants of bank risk. Credit risk is important as an increase in the variable would signal weakening of the credit portfolio and the overall deterioration in banks' asset quality. Alternatively, it can be argued that greater loan loss provisions explain that banks are at more nonperforming risky loans exposure. The second measure is liquidity risk expressed as the ratio of liquid assets to total assets, LIQTA (Arnold et al., 2016; Hadad et al., 2011). Liquidity risk accentuates banks to hold sufficient reserves and liquid assets, thus, be able to liquidate due debts and avoid loss of depositors' confidence. In the ex-post global financial crisis, the drivers of liquidity risk issue had been given remarkable interest (Wójcik-Mazur \& Szajt, 2015), and Basel III is placing greater emphasis on liquidity monitoring tools. The last bank risk metric is $\mathrm{z}$-score. It is chosen because it captures and predicts overall bank default risk and stability (Fosu et al., 2017; Hadad et al., 2011; Laeven \& Levine, 2009). Z-score is the number of standard deviations that the profit must fall to drive a firm into insolvency in bankruptcy ground. It is constructed as the inverse of the return on assets plus equity assets ratio divided by the standard deviation of return on assets. More formally, it is estimated as $(\mathrm{ROA}+$ capital/asset ratio)/ $\sigma(\mathrm{ROA})$. It can be conjectured that the larger the Z-score (i.e. distance to default), the lower a firm is at probability of default risk.

The primary independent variable is market discipline (MD). Following prior studies (Fazelina Sahul \& Norhanishah Mohd, 2017; Hoang et al., 2014; Nier \& Baumann, 2006), market discipline is measured as interbank deposit scaled by total deposit. Consistent with the augment that market discipline reduces risk, interbank deposits variable is selected as is not covered by explicit deposit in- 
surance policy and banks are expected to be informed investors on the magnitude of risk through the interbank market. Apparently, incredible market discipline indicator would lead to an increase in bank risk-taking. Hence, the prediction is that a negative coefficient of MD in LLPTL, and a positive coefficient of MD in both LIQTA and z-score explain for bank risk reduction. Other variable of interest is bank capital. It is defined as Tier 1 capital to risk-weighted assets (Tier 1 capital). It has been used in a number of studies to predict bank risk. Tier 1 capital coefficients are expected to reveal similar pattern of coefficients as MD coefficient in the alterative bank risk measures. The underlying argument is that bank capital is the risk-based regulatory device whereby bigger capital buffer tends to reduce banks' incentives behavior to pursue aggressive risk strategies. In turn, risk-based core capital provides upper bound on the likelihood of bank insolvency. The other independent variables specific to bank risk are selected based on studies by Galloway et al. (1997), Stiroh (2006), Haq \& Heaney (2012), Hoang et al. (2014), among others. They include off-balance sheet activities (OBS), revenue diversification index (RDI) and size.

The Banking and Financial Institution Act $(1990,2006)$ gave rise to banks engaging in OBS trading and diversification strategy. Through this approach, banks boosted their revenue income and OBS activities impact bank risk. Angbazo (1997), Haq \& Heaney (2012) and Hoang et al. (2014) show that OBS items are either positively or negatively on bank risk, implying ambiguous relationship. Haq et al. (2019) argue that the escalation in bank failures and the increased level of OBS activities may lead to a positive relation. The RDI formally defined in Equation (1), and can carry negative or positive sign in risk. The negative association centres on the notion that large banks tend to be more diversified (Hoang et al., 2014; Konishi \& Yasuda, 2004; Stiroh, 2006), and a move towards noninterest generating activities may lead to positive relation as argued by Hoang et al. (2014). RDI displays an increasing and decreasing behaviour on bank risk in Hoang et al. (2014). Moreover, large banks finds it easier to access capital market, hence, this strategy might help to mitigate their liquidity risk (Haq \& Heaney, 2012). Bank size is measured by total assets $(\operatorname{lnTa})$. Because of the diversification effect, $\ln \mathrm{Ta}$ is predicted to be negative as per extant studies (Haq \& Heaney, 2012; Stiroh, 2006) or positive (Enkhbold \& Otgonshar, 2013; Hoang et al., 2014; Saunders, Strock, \& Travlos, 1990) in risk, following the general market movement. For the general macroeconomic environment, year dummies (D09-D17) are included to capture inflation and GDP growth variations in market conditions (Flannery \& Sorescu, 1996) on bank risk. Following Stiroh (2006) and Hoang et al. (2014), RDI is constructed in Equation (1) as:

$$
\mathrm{RDI}=1-\left(\mathrm{SH}_{\mathrm{NET}}^{2}-\mathrm{SH}_{\mathrm{NON}}^{2}\right)
$$

where: $\mathrm{SH}_{\mathrm{NET}}$ : share of net operating income from net interest sources;

$\mathrm{SH}_{\mathrm{NON}}$ : share of net operating income from noninterest sources;

NET: net interest income; 
NON: noninterest income;

$\mathrm{SH}_{\mathrm{NET}}=\mathrm{NET} /(\mathrm{NET}+\mathrm{NON})$, and $\mathrm{SH}_{\mathrm{NON}}=\mathrm{NON} /(\mathrm{NET}+\mathrm{NON})$.

\subsection{Research Method}

The main estimation technique is fixed effects panel regressions. It is chosen over other estimators for two reasons. First, it captures and addresses unobserved bank fixed effects in the panel regressions for the entire data set together with year dummies as proposed by Wooldridge (2010). Second, the focus variable, MD is time-varying explanatory variable. This variable varies over time as its components-i.e. interbank deposits and total deposits repeatedly change. Taking guidance of the discussion on Section 2.1, bank risk is conditioned on market discipline and other control variables as in Haq \& Heaney (2012), Enkhbold \& Otgonshar (2013), and Hoang et al. (2014), Risk ${ }_{i, t}$ is estimated as follows in econometric Equation (2):

$$
\begin{aligned}
\text { Risk }_{i, t}= & \alpha+\beta_{1} \text { Risk }_{i, t-1}+\beta_{2} \mathrm{MD}_{i, t}+\beta_{3} \mathrm{MD}_{i, t}^{2}+\beta_{4} \text { Tierl }_{i, t}+\beta_{5} \mathrm{OBS}_{i, t} \\
& +\beta_{6} \mathrm{RDI}_{i, t}+\beta_{7} \mathrm{SIZE}_{i, t}+\beta_{8} \sum \delta \gamma_{i, t}+\varepsilon_{i, t}
\end{aligned}
$$

where $\beta_{1}$ Risk $_{i, t-1}$ : risk measure for bank $i$ in period $t$ lagged one period-loan loss provisions, liquid assets and $\mathrm{z}$-score, as defined above.

$\mathrm{MD}_{i, t}$ : market discipline for bank $i$ in period $t$.

$\mathrm{MD}_{i, t}^{2}$ : square of market discipline for bank $i$ in period $\mathrm{t}$.

Tier $_{i, t}$ : bank capital for bank $i$ in period $t$.

$\mathrm{RDI}_{i, t}$ : revenue diversification index for bank $i$ in period $t$.

$\mathrm{OBS}_{i, t}$ : natural log of off-balance sheet activities for bank $i$ in period $t$.

$\mathrm{SIZE}_{i, t}$ : natural log of bank asset for bank $i$ in period $t$.

$\Sigma \delta y_{i, i}$ year dummies (D09-D17).

\subsection{Descriptive Statistics and Pair-Wise Correlations}

Table 1 contains the key descriptive statistics of all dependent and explanatory variables. Referring to the risk parameters-LLPTL reveals the mean (median) of $1.945 \%(1.020 \%)$ with a range of $-1.430 \%$ to $100 \%$, implying higher magnitude of heterogeneity across banks. The LLPLT exhibits a high level of variability represented by standard deviation of 6.409 , which is approximately three times of its mean. LIQTA indicates a range from $11.380 \%$ to $84.820 \%$. z-score displays a mean (median) of 0.015 (0.008). Compared to LLPLT, these two variables show insignificant amount of variations. Turning to explanatory variables, market discipline, MD shows mean (median) of $7.443 \%(3.150 \%)$ with a lowest 0 and highest is $48.250 \%$. MD's standard deviation is 9.219 which is 1.24 times of its mean, suggesting moderate market discipline across banks. The mean (median) of bank capital, Tier 1 is $26.115 \%$ (17\%), with 41.166 standard deviation. On average, they are above the minimum core capital requirement of $10 \%$. This implies that Tanzanian commercial banks comply with the risk-based core capital regulation requirement. The variation in observations from 283 to 282 was 
Table 1. Descriptive statistics.

\begin{tabular}{ccccccc}
\hline Variables & Obs & Mean & Median & SD & Min & Max \\
\hline LLPL & 283 & 1.945 & 1.020 & 6.409 & -1.430 & 100.000 \\
LIQTA & 283 & 42.821 & 41.640 & 13.598 & 11.380 & 84.820 \\
Z-score & 282 & 0.015 & 0.008 & 0.034 & 0.000 & 0.509 \\
MD & 283 & 7.443 & 3.150 & 9.219 & 0.000 & 48.250 \\
Tier1 & 282 & 26.115 & 17.000 & 41.166 & -24.160 & 466.270 \\
RDI & 283 & 0.691 & 0.680 & 0.295 & -0.520 & 2.000 \\
OBS & 282 & 17.651 & 11.903 & 24.972 & -0.461 & 262.754 \\
$\ln T a$ & 282 & 26.247 & 26.055 & 1.315 & 22.380 & 29.390 \\
\hline
\end{tabular}

attributed to missing data in some banks.

Table 2 presents pair-wise correlation matrix between variables. It is shown that market discipline is negatively correlated for credit risk, LLPL (0.044), as predicted. Contrary to expectation, market discipline is negative in liquidity risk, LIQTA and z-score (0.044) and (0.057), respectively. Generally, this initial result shed some light that market discipline exists and reduced risk-taking in Tanzanian commercial banks, as hypothesized in H1. Approximately, correlations among all independent variables exhibited statistically insignificant. And yet, large correlation coefficient is between SIZE and core capital Tier 1 (0.363). Next, bank size is orthogonalized against bank core capital Tier 1 in order to lessen multicollinearity concern.

\section{Empirical Results}

\subsection{Market Discipline and Bank Risk}

Table 3 reports the results of the fixed effects (within) estimates for the main risk regression Equation (2) in three columns. Columns (1) - (3) use LLPTL, LIQTA, and z-score as all proxies for bank risk as dependent variables, respectively. It is clearly evident that there are conflicting results pertaining to market discipline and alternative bank risk measures. Specifically, in column (1), the finding consistently indicates that market discipline is statistically significant and negatively related to LLPTL at $5 \%$ level. And it is in accordance with the prediction of the interbank market disciplining Tanzanian banks from risk taking behaviour. Empirically, the result is in contrast to Nier \& Baumann (2006) and the more recent research connecting market discipline and bank risk-taking by Hoang et al. (2014) and Fazelina Sahul \& NorhanishahMohd (2017). Yet, the finding contradicts with that reported by Haq \& Heaney (2012) and Fosu et al. (2017). The latter two papers indicate a positive association between uninsured deposits (market discipline proxy) and bank risk (credit risk and idiosyncratic risk). Arguably market discipline improved banks' asset quality portfolio by downsizing the magnitude of nonperforming loans value. A possible explanation for this finding could be that when credible and quality market discipline is 
Table 2. Pair-wise correlation.

\begin{tabular}{cccccccc}
\hline Variable & LLPL & LIQTA & z-score & MD & Tier 1 & RDI & OBS \\
\hline LLPL & 1.000 & & & & & & \\
LIQTA & -0.046 & 1.000 & & & & & \\
z-score & $0.118^{*}$ & 0.004 & 1.000 & & & & \\
MD & -0.044 & -0.044 & -0.057 & 1.000 & & & \\
Tier 1 & -0.048 & $0.503^{*}$ & 0.043 & $-0.128^{*}$ & 1.000 & & \\
RDI & 0.028 & $0.247^{*}$ & 0.058 & 0.004 & $0.166^{*}$ & 1.000 & \\
OBS & 0.051 & 0.020 & 0.111 & -0.034 & $-0.148^{*}$ & 0.102 & 1.000 \\
InTa & -0.002 & $-0.197^{*}$ & 0.052 & -0.004 & $-0.363^{*}$ & 0.109 & $0.231^{*}$ \\
\hline
\end{tabular}

Asterisk * indicates statistical significance at the level of $5 \%$.

exercised, bank excessive risk-taking incentives can be attenuated. This is due to the fact that uninsured bank debtholders are exposed to bank failure risk; therefore, they tend to discipline banks for their bad behaviour. That is when banks' risk exposures increase debtholders (on this case interbank market participants) may discipline banks with the mechanisms highlighted above.

One independent variable appears to drive bank risk (credit risk). It is off-balance items, OBS. The variable is positive and significant associated with LLPTL at 5\% level. Comparable findings are indicated in Angbazo (1997), Haq \& Heaney (2012) and Hoang et al. (2014). This result may explain and offers two important insights. One is the growth of nontraditional banking activities in Tanzanian banks, which, in turn would have increased risk taking and boosted banks' income. Two, banks engaged in considerable exposures to off-balance sheet financial vehicles and this aggravated excessive risk-taking (i.e. probability to insolvency risk). Results for liquidity risk, LIQTA are presented in column (2). The regression coefficient of market discipline is as unexpected. It is negative and statistically insignificant $\mathrm{t}$-statistics in LIQTA. This finding translates into that market discipline did not increase bank liquidity risk. Based on this result, it cannot be perceived as a practice that market discipline is not in existence and technically incredible in reducing liquidity risk for the banking sector in Tanzanian environment. To ensure bank liquidity problems is kept at acceptable level, government liquidity policies and guidelines that advocate to liquidity management and funding are in place. The no relation finding further may be explained by dearth underdeveloped high quality liquid asset instruments $(\mathrm{HQLA})^{2}$ in Tanzanian banking sector. In addition, bank capital is positive and statistically significant related to bank liquidity risk at $1 \%$ level, suggesting that higher capital constrained bank to to excessive liquidity risk. With this regard, when bank risk increases, capital needs to be proportionally amplified or bank lending activities should be curtailed and restructured accordingly. Some previous

${ }^{2}$ Bank for International Settlements refers the HQLA as assets that can be easily and immediately converted into cash at a little or no loss of value. And liquidity of asset depends on the underlying stress scenario, the volume to be monetized and the timeframe considered. 
Table 3. H1-Analysis of bank risk as a function of market discipline (baseline model).

\begin{tabular}{|c|c|c|c|}
\hline Dependent variable & LLPTL & LIQTA & z-score \\
\hline Independent variable & (1) & (2) & (3) \\
\hline \multirow[t]{2}{*}{ MD } & $-0.126^{\star *}$ & -0.006 & -0.083 \\
\hline & $(-2.385)$ & $(-0.279)$ & $(-1.172)$ \\
\hline \multirow[t]{2}{*}{ Tier1 } & -0.177 & $0.241^{\star * *}$ & $-0.579^{\star *}$ \\
\hline & $(-0.510)$ & $(2.808)$ & $(-2.207)$ \\
\hline \multirow[t]{2}{*}{ OBS } & $0.018^{\star *}$ & 0.002 & 0.003 \\
\hline & $(2.044)$ & $(1.065)$ & $(0.744)$ \\
\hline \multirow[t]{2}{*}{ RDI } & -0.010 & 0.007 & 0.066 \\
\hline & $(-0.022)$ & $(0.140)$ & $(0.183)$ \\
\hline \multirow[t]{2}{*}{ InTa } & 0.229 & -0.015 & $-0.437^{\star * *}$ \\
\hline & $(0.570)$ & $(-0.618)$ & $(-2.760)$ \\
\hline \multirow[t]{2}{*}{ D09 } & 0.000 & 0.060 & -0.547 \\
\hline & omitted & $(1.086)$ & $(-1.466)$ \\
\hline \multirow[t]{2}{*}{ D10 } & 0.483 & $0.140^{* *}$ & $-0.884^{*}$ \\
\hline & $(1.208)$ & $(2.527)$ & $(-1.696)$ \\
\hline \multirow[t]{2}{*}{ D11 } & -0.018 & 0.020 & -0.538 \\
\hline & $(-0.043)$ & $(0.440)$ & $(-1.275)$ \\
\hline \multirow[t]{2}{*}{ D12 } & 0.390 & -0.060 & -0.249 \\
\hline & $(0.879)$ & $(-0.980)$ & $(-0.651)$ \\
\hline \multirow[t]{2}{*}{ D13 } & 0.321 & -0.109 & -0.153 \\
\hline & $(0.815)$ & $(-1.426)$ & $(-0.397)$ \\
\hline \multirow[t]{2}{*}{ D14 } & 0.151 & -0.041 & $-0.599^{*}$ \\
\hline & $(0.360)$ & $(-0.729)$ & $(-1.770)$ \\
\hline \multirow[t]{2}{*}{ D15 } & 0.535 & $-0.083^{\star}$ & -0.510 \\
\hline & $(1.016)$ & $(-1.722)$ & $(-1.641)$ \\
\hline \multirow[t]{2}{*}{ D16 } & 0.270 & $-0.080^{* *}$ & -0.106 \\
\hline & $(0.508)$ & $(-2.151)$ & $(-0.383)$ \\
\hline \multirow[t]{2}{*}{ D17 } & 0.796 & - & - \\
\hline & $(1.457)$ & omitted & omitted \\
\hline \multicolumn{4}{|l|}{ Model Fits } \\
\hline F-test & $8.158^{\star * *}$ & $6.841^{\star * *}$ & $3.087^{\star * *}$ \\
\hline R2_within & 0.176 & 0.250 & 0.005 \\
\hline R2_adjusted & 0.112 & 0.200 & 0.054 \\
\hline $\mathrm{N}$ & 181 & 208 & 208 \\
\hline
\end{tabular}

This table reports the fixed effects (within) of a linear panel estimation results in which each bank is permitted to have its own (unreported) intercept term. Results are corrected for heteroskedasticity and robust $\mathrm{t}$-values are shown in the brackets below the estimates, with ${ }^{*},{ }^{* *}$, and ${ }^{* * *}$ indicating significance at the $10 \%$, $5 \%$, and $1 \%$ levels, respectively. 
studies document negative connections, as discussed above [(see, Klomp \& Haan (2012) and Lotto (2016)].

In column (3), the response variable is z-score. The coefficient estimate on $\mathrm{MD}$ is negative and statistically insignificant $\mathrm{t}$-statistics. The absence of relation could be driven by legal and institutional frameworks setting. Other important variables that moderated market discipline are Tier1 and $\ln$ Ta. The sign of Tier 1 coefficient is significant negative for insolvency risk at $5 \%$ level, supporting the view in Koehn \& Santomero (1980) that higher capitalization may induce bank to choose risky portfolios. The finding compares with those in Klomp \& Haan (2012) and Lotto (2016).

$\mathrm{Z}$-score is negatively associated with $\ln \mathrm{Ta}$ at $1 \%$ level of significance. This result implies that for high sized value banks, the overall bank probability to bankruptcy risk can be mitigated via diversification strategy in holding more assets portfolios. In summary, the results are mixed with respect to the link between bank risk and market discipline. Yet, they offer some empirical evidence articulating that Tanzania is not unique, rather market discipline exists and reduced risk-taking in commercial banks, which corroborates $\mathrm{H} 1$.

\subsection{Nonlinearity between Market Discipline and Bank Risk}

Table 4 presents the estimation results of nonlinearity between market discipline and bank risk. The nonlinearity is measured by $\mathrm{MD}^{2}$. In model specifications, MD is negative and statistically insignificant related to bank risk across columns (2) - (3), and is positive statistically significant in LLPTL at 10\% level, column (1). In comparison, the coefficients of $\mathrm{MD}^{2}$ are insignificant in bank risk. It is evident that this study did not find a statistically significant link for the nonlinear between $\mathrm{MD}^{2}$ and bank risk. This empirical evidence, thereore contradicts the theoretical guidance by Gorton \& Santomero (1990).

The failure of risk measures (i.e. credit risk, liquidity risk and insolvency risk) as predictors of market discipline in this specification model could be due to the institutional environment in Tanzania banking sector. Hence, $\mathrm{H} 2$ is rejected.

\subsection{Market Discipline in Response to Bank Holding Capital Buffer}

Table 5 exhibits the regression estimation results for the interaction of market discipline and Tier1 capital, $\mathrm{MD}^{\star}$ Tier1 on bank risk. In columns (1) - (2), the coefficients of $\mathrm{MD}^{\star}$ Tier1 are positive and insignificant. Contrary to anticipation, in column (3), it is found that both parameter estimates on MD*Tier1 and MD are negative and positive and statistically significant on $\mathrm{z}$-score at $1 \%$ levels, respectively. The explanation to this result is that, effectiveness of market discipline on the presence of bank capital may be not worth mentioning in the reduction of excessive bank risk-taking. Alternative view is that, presence of bank capital can weaken market discipline strength to the extent of increasing insolvency risk as revealed by the decrease in $\mathrm{z}$-score (i.e. distance to default). The finding is inconsistent with that documented in Hoang et al. (2014). By this perception, 
Table 4. H2-Analysis of bank risk as a function of market discipline squared.

\begin{tabular}{|c|c|c|c|}
\hline Dependent variable & LLPTL & LIQTA & z-score \\
\hline Independent variable & (1) & (2) & (3) \\
\hline \multirow[t]{2}{*}{ MD } & $-0.104^{\star}$ & -0.011 & -0.085 \\
\hline & $(-2.018)$ & $(-0.488)$ & $(-1.131)$ \\
\hline \multirow[t]{2}{*}{$\mathrm{MD}^{2}$} & 0.000 & 0.000 & 0.000 \\
\hline & $(-1.153)$ & $(1.065)$ & $(0.108)$ \\
\hline \multirow[t]{2}{*}{ Tier1 } & -0.242 & $0.257^{\star * *}$ & $-0.571^{\star}$ \\
\hline & $(-0.716)$ & $(3.037)$ & $(-1.930)$ \\
\hline \multirow[t]{2}{*}{ RDI } & -0.115 & 0.024 & 0.074 \\
\hline & $(-0.242)$ & $(0.439)$ & $(0.190)$ \\
\hline \multirow[t]{2}{*}{ OBS } & $0.017^{\star}$ & 0.002 & 0.004 \\
\hline & $(1.846)$ & $(1.241)$ & $(0.742)$ \\
\hline \multirow[t]{2}{*}{$\ln \mathrm{Ta}$} & 0.283 & -0.019 & $-0.439^{\star * *}$ \\
\hline & $(0.659)$ & $(-0.666)$ & $(-2.784)$ \\
\hline D09-D17 & Included & Included & included \\
\hline \multicolumn{4}{|l|}{ Model Fits } \\
\hline F-test & $8.534^{* * *}$ & $6.917^{\star * *}$ & $2.898^{\star * *}$ \\
\hline $\mathrm{R}^{2}$ & 0.113 & 0.202 & 0.049 \\
\hline $\mathrm{N}$ & 181 & 208 & 208 \\
\hline
\end{tabular}

This table reports the fixed effects (within) of nonlinear panel estimation results in which each bank is permitted to have its own (unreported) intercept term. Results are corrected for heteroskedasticity and robust $\mathrm{t}$-values are reported in the brackets below the estimates, with ${ }^{\star},{ }^{* *}$, and ${ }^{\star * *}$ indicating significance at the $10 \%, 5 \%$, and $1 \%$ levels, respectively.

the positive and negative coefficients on MD and Tier1, respectively might suggest the complementarity effect to bank risk-taking.

Both factors are intended to curb an adverse outcome in the bank portfolio risk for the financial stability (Nier \& Baumann, 2006). By this intuition, H3 is rejected. Accordingly, this result hints policy implication. Next, the coefficient on the $\ln \mathrm{Ta}$ is negative and statistically significant at $1 \%$ level, similar to that indicated in Table 3. Other interesting parameter estimate is OBS with a positive sign and significant at $10 \%$ level, reflecting an increase in bank risk, in column (1). Finally, across all model specifications, the mean VIFs are less than 10, indicating absence of multicollinearity among explanatory variables.

\section{Further Robustness Checks}

To check for robustness to the original results reported in Table 3, this study conducts two tests and their findings are presented on Table 6. One, the sample was divided into two sub-samples, with 2013 selected as the cutoff point year for 
Table 5. H3-Analysis of bank risk as a function of the interaction market discipline bank capital.

\begin{tabular}{|c|c|c|c|}
\hline Dependent variable & LLPTL & LIQTA & z-score \\
\hline Independent variable & (1) & (2) & (3) \\
\hline \multirow[t]{2}{*}{$\mathrm{MD}$} & -0.169 & -0.081 & $0.839^{* * *}$ \\
\hline & $(-0.420)$ & $(-0.805)$ & $(3.150)$ \\
\hline \multirow[t]{2}{*}{ MD*Tier 1} & 0.013 & 0.025 & $-0.296^{* * *}$ \\
\hline & $(0.095)$ & $(0.858)$ & $(-3.360)$ \\
\hline \multirow[t]{2}{*}{ Tier 1} & -0.014 & $0.007^{* *}$ & 0.003 \\
\hline & $(-0.718)$ & $(2.566)$ & $(0.455)$ \\
\hline \multirow[t]{2}{*}{ RDI } & -0.021 & 0.074 & 0.263 \\
\hline & $(-0.046)$ & $(0.974)$ & $(0.649)$ \\
\hline \multirow[t]{2}{*}{ OBS } & $0.017^{\star}$ & 0.001 & $0.008^{*}$ \\
\hline & $(1.913)$ & $(0.662)$ & $(1.736)$ \\
\hline \multirow[t]{2}{*}{$\ln \mathrm{Ta}$} & 0.238 & -0.011 & $-0.499^{* * *}$ \\
\hline & $(0.561)$ & $(-0.502)$ & $(-3.323)$ \\
\hline D09-D17 & Included & Included & Included \\
\hline \multicolumn{4}{|l|}{ Model Fits } \\
\hline F-test & $7.841^{* * *}$ & $7.138^{* * *}$ & $5.767^{* * *}$ \\
\hline $\mathrm{R} 2$ & 0.110 & 0.202 & 0.077 \\
\hline $\mathrm{N}$ & 181 & 208 & 208 \\
\hline
\end{tabular}

This table reports the fixed effects (within) of the interaction of $\mathrm{MD}^{*}$ Tier 1 panel estimation results in which each bank is permitted to have its own (unreported) intercept term. Results are corrected for heteroskedasticity and robust $\mathrm{t}$-values are reported in the brackets below the estimates, with ${ }^{*},{ }^{* *}$, and ${ }^{* * *}$ indicating significance at the $10 \%, 5 \%$, and $1 \%$ levels, respectively.

provisioning in deteriorating credit risk environment by using a dummy variable LLP2012, The variable equal to 1 if the period is pre-2009-2012 and zero if post-2013-2017. The 2013 year is chosen as a cutoff point because nonperforming loans to gross loans trended down from $22.6 \%$ in $2008-2010$ to $20.8 \%$ in 2011-2013 before rising to $23.2 \%$ in 2014-2017. Equally, the provision for bad debts to gross loans depicted downward trend from $5.6 \%$ in $2008-2010$ to $2.8 \%$ in 2011-2013, then, rose to 6.9\% in 2014-2017 (Mbowe et al., 2020). Next, an interaction variable LLP2012MD is constructed. The variable tests the effect of market discipline in both pre- and post- credit risk structural changes. Contrary to expectation, in column (1), Panel A, the parameter estimate on LLP2012MD is statistically significant and negative at 1\% level in LLPTL in the pre-2009-2012 credit risk environment. This finding compares with that and is robust to the original result shown in Table 3. As column (3) shows, the overall bank default risk as measured by $z$-score, LLP2012MD is statistically significant at $5 \%$ level, with the anticipated negative sign. The result can be explained as that the drop in distance to default coming from the weak market discipline in curbing the 
Table 6. Regression bank risk as a function of market discipline (baseline model).

\begin{tabular}{|c|c|c|c|c|c|c|}
\hline \multirow[b]{2}{*}{ Dependent variable } & \multicolumn{3}{|c|}{ Panel A: Sub-sample-fixed effect } & \multicolumn{3}{|c|}{ Panel B: Full-sample_two step GMM system } \\
\hline & LLPTL & LIQTA & z-score & LLPTL & LIQTA & z-score \\
\hline Independent variable & (1) & (2) & (3) & (4) & (5) & (6) \\
\hline \multirow[t]{2}{*}{ L.LLPTA } & & & & $0.214^{*}$ & & \\
\hline & & & & $(1.708)$ & & \\
\hline \multirow[t]{2}{*}{ L.LIQTA } & & & & & 0.315 & \\
\hline & & & & & $(1.205)$ & \\
\hline \multirow[t]{2}{*}{ L.z-score } & & & & & & 0.103 \\
\hline & & & & & & $(0.570)$ \\
\hline \multirow[t]{2}{*}{ MD } & -0.007 & 0.002 & 0.003 & $-0.241^{\star *}$ & 0.051 & $-0.467^{\star *}$ \\
\hline & $(-0.585)$ & -0.540 & -0.420 & $(-2.224)$ & $(0.627)$ & $(-2.103)$ \\
\hline \multirow[t]{2}{*}{ LLP_2012MD } & $-0.047^{\star * *}$ & -0.005 & $-0.046^{* *}$ & & & \\
\hline & $(-2.885)$ & $(-1.570)$ & $(-2.703)$ & & & \\
\hline \multirow[t]{2}{*}{ Tier1 } & -0.037 & $0.251^{* * *}$ & -0.123 & 0.498 & $0.366^{*}$ & -0.418 \\
\hline & $(-0.144)$ & $(6.951)$ & $(-0.750)$ & -0.372 & $(1.890)$ & $(-0.817)$ \\
\hline \multirow[t]{2}{*}{ OBS } & $0.014^{* * *}$ & 0.001 & 0.004 & -0.009 & -0.014 & 0.044 \\
\hline & (3.838) & $(0.928)$ & $(1.536)$ & $(-0.182)$ & $(-1.146)$ & $(0.810)$ \\
\hline \multirow[t]{2}{*}{ RDI } & -0.549 & 0.029 & 0.250 & -0.716 & -0.068 & 1.659 \\
\hline & $(-1.120)$ & $(0.819)$ & $(0.885)$ & $(-0.722)$ & $(-0.217)$ & (1.387) \\
\hline \multirow[t]{2}{*}{$\ln \mathrm{Ta}$} & 0.299 & -0.034 & $-0.351^{\star *}$ & $0.855^{\star}$ & -0.148 & 0.001 \\
\hline & $(0.859)$ & $(-1.195)$ & $(-2.628)$ & -1.894 & $(-1.547)$ & $(0.002)$ \\
\hline LLP_2012 & -0.129 & -0.024 & 0.266 & & & \\
\hline \multicolumn{7}{|l|}{ Model fits } \\
\hline $\mathrm{F}$ & 40.511 & 19.622 & 4.756 & $8.481^{\star * *}$ & $5.538^{* * *}$ & 1.62 \\
\hline $\mathrm{R} 2$ & 0.182 & 0.372 & 0.066 & & & \\
\hline Hansen J-test & & & & 6.20 & 3.65 & 9.20 \\
\hline $\mathrm{AR}(1)$ & & & & $-2.60^{\star * *}$ & $-1.94^{*}$ & $-2.79^{\star * *}$ \\
\hline $\operatorname{AR}(2)$ & & & & -0.02 & 0.00 & -0.90 \\
\hline $\mathrm{N}$ & 230 & 274 & 274 & 138 & 185 & 185 \\
\hline
\end{tabular}

The heterosedasticity consistent $\mathrm{t}$-statistics based on robust standard errors are reported in parentheses, ${ }^{*}{ }^{* *}$, and ${ }^{* * *}$ indicate statistical significance at the $10 \%, 5 \%$, and $1 \%$ levels, respectively.

increased risk taking over pre-2009-2012 credit risk structural change in Tanzanian banking sector.

The second robustness test is motivated by the belief that a causal relationship from market discipline to bank risk and both of them are endogenous. The evidence reported in Section 4 could therefore suffer endogenous problem-i.e. there likelihood of regressors (exogenous variables) correlated with the error terms. Moreover, in a dynamic panel setting, the results might endure other un- 
observed heterogeneity. To address these concerns, the study, therefore, employed two-step system GMM estimator (Arellano \& Bond, 1991; Arellano \& Bover, 1995; Blundell \& Bond, 1998). For GMM results, Panel B, columns (4) (6), the estimated coefficient on market discipline, MD, remain statistically significant and negatively related to LLPTL at $5 \%$ level in column (4). It is robust to those indicated in Table 3. The one-year prior LLPTL is positive and significant at $10 \%$ level in column (3). This finding suggests that lagged levels of LLPTL contain information on current loan loss provision, LLPTL. In column (6), the overall bank default risk as captured by z-score is statistically significant and negative at $5 \%$ level on the coefficient of $\mathrm{MD}$, implying that market discipline provoked risk in banks.

By using two-step system GMM estimator, the diagnostic tests reveal that the models are well fitted for both second order serial correlation in the second differences $\operatorname{AR}(2)$ and Hansen J-statistics of over-identifying restrictions. Hansen J-statistics shows that instruments are valid and that the moments are satisfied. Accordingly, AR(2) and Hansen J-statistics tests are statistically insignificant in all bank risk measures. And the test for first order serial correlation, $\operatorname{AR}(1)$ is statically significant across risk proxies, at around 5\% level. The number of instruments employed is less than the panel-i.e. 32 firms.

\section{Concluding Remarks}

This paper tested the fundamental question over the presence of market discipline on Tanzanian banks, and whether it matters in the reduction of bank risk. Three risk metrics: credit risk, liquidity risk and insolvency risk were regressed on market discipline, bank characteristics and control variables. By using unbalanced panel of 32 commercial banks data over the period 2009-2017, in fixed effects estimator the paper documented the following primary result:

1) Overall, the results are mixed. This is evident when market discipline is connected with alternative bank risk measures in different model specifications. However, there is some indication from the findings reported here that market discipline reduced bank risk. In particular, market discipline is negative and statistically significant for credit risk, similar with that found in Hoang et al. (2014).

2) Empirical evidence is shown between the interaction of market discipline and bank capital, and bank risk (z-score) is negatively associated. It is argued that the presence of bank capital in moderating market discipline for reducing bank risk is not noteworthy. This is because this interaction enhanced insolvency risk.

3) It is found that bank characteristics (i.e. bank capital, off-balance items, and contrary) better explained the variation in bank risk.

4) The paper did not observe the nonlinearity relation between market discipline and bank risk, therefore, inconsistent with the theoretical argument by Gorton \& Santomero (1990). This lack of any obvious association would have been driven by weak institutional framework and infant financial market. 
5) The results have policy implication that hints banks' regulators and policymakers to reinforce market discipline framework when contemplating banks' risk taking responses. That is sound market discipline practice can attenuate excessive risk taking behaviour in banks and restore financial stability. There is therefore necessity to implement vigorous and practical market discipline policies, like the issuance of SNDs mandatory as part of paital by large commercial banks in Tanzania. Such adoption may enhance the efficacy of market discipline in curbing bank excessive risk-taking in Tanzania.

\section{Limitations}

This study suffers two limitations. First, the risk proxy, z-score used may be problematic. In some banks, the underestimate of loan loss provisions constructed from nonperforming loans may have had resulted into overstating profit before interest and tax. The same effect could be true for ROA. Ensuing this irregularity, the estimated z-score used may be an issue. Second, few moderating variables are employed in this study (for more constrained variables, see Fazelina Sahul \& Norhanishah Mohd, 2017; Hoang et al., 2014). Noting these drawbacks, the investigation of bank risk sensitivity to market discipline when charter value is constrained is less examined in the empirical banking evidence, thus, meriting future research.

\section{Acknowledgements}

The author wishes to thanks unanimous reviewer, Krishna Paundyal, Geofry Areneke and seminar participants at the 9th African Accounting and Finance Conference, University of Dar es Salaam, Tanzania, held: 4th-6th September, 2019. The views expressed in this paper are of the author only and he is responsible for any remaining errors.

\section{Conflicts of Interest}

The author declares no conflicts of interest regarding the publication of this paper.

\section{References}

Angbazo, L. (1997). Commercial Bank Net Interest Margins, Default Risk, Interest-Rate Risk, and Off-Balance Sheet Banking. Journal of Banking \& Finance, 21, 55-87. https://doi.org/10.1016/S0378-4266(96)00025-8

Anginer, D., Demirgüç-Kunt, A., \& Mare, D. S. (2018). Bank Capital, Institutional Environment and Systemic Stability. Journal of Financial Stability, 37, 97-106. https://doi.org/10.1016/j.jfs.2018.06.001

Arellano, M., \& Bond, S. (1991). Some Tests of Specification for Panel Data: Monte Carlo Evidence and an Application to Employment Equations. The Review of Economic Studies, 58, 277-297. https://doi.org/10.2307/2297968

Arellano, M., \& Bover, O. (1995). Another Look at the Instrumental Variable Estimation of Error-Components Models. Journal of Econometrics, 68, 29-51. 
https://doi.org/10.1016/0304-4076(94)01642-D

Arnold, E. A., Grössl, I., \& Koziol, P. (2016). Market Discipline across Bank Governance Models: Empirical Evidence from German Depositors. The Quarterly Review of Economics and Finance, 61, 126-138. https://doi.org/10.1016/j.qref.2015.12.002

Baer, H., \& Brewer, E. (1986). Uninsured Deposits as a Source of Market Discipline: Some New Evidence. Economic Perspectives, 10, 23-31.

Bakkar, Y., Rugemintwari, C., \& Tarazi, A. (2017). Charter Value and Bank Stability before and after the Global Financial Crisis of 2007-2008. https://doi.org/10.2139/ssrn.2800616

Balasubramnian, B., \& Cyree, K. B. (2011). Market Discipline of Banks: Why Are Yield Spreads on Bank-Issued Subordinated Notes and Debentures Not Sensitive to Bank Risks? Journal of Banking \& Finance, 35, 21-35. https://doi.org/10.1016/j.jbankfin.2010.07.015

Bennett, R. L., Hwa, V., \& Kwast, M. L. (2015). Market Discipline by Bank Creditors during the 2008-2010 Crisis. Journal of Financial Stability, 20, 51-69. https://doi.org/10.1016/j.jfs.2015.06.003

Berger, A. N. (1991). Market Discipline in Banking. Federal Reserve Bank of Chicago Proceedings. https://ideas.repec.org/p/fip/fedhpr/328.html

Bertay, A. C., Demirgüç-Kunt, A., \& Huizinga, H. (2013). Do We Need Big Banks? Evidence on Performance, Strategy and Market Discipline. Journal of Financial Intermediation, 22, 532-558. https://doi.org/10.1016/j.jfi.2013.02.002

Blundell, R., \& Bond, S. (1998). Initial Conditions and Moment Restrictions in Dynamic Panel Data Models. Journal of Econometrics, 87, 115-143. https://doi.org/10.1016/S0304-4076(98)00009-8

Brandao-Marques, L., Correa, R., \& Sapriza, H. (2018). Government Support, Regulation, and Risk Taking in the Banking Sector. Journal of Banking \& Finance, 112, Article ID: 105284. https://doi.org/10.1016/j.jbankfin.2018.01.008

Calomiris, C. W., \& Jaremski, M. (2019). Stealing Deposits: Deposit Insurance, Risk-Taking, and the Removal of Market Discipline in Early 20th-Century Banks. The Journal of Finance, 74, 711-754. https://doi.org/10.1111/jofi.12753

De Mendonca, H. F., \& Loures, R. F. V. (2009). Market Discipline in the Brazilian Banking Industry: An Analysis for the Subordinated Debt Holders. Journal of Regulatory Economics, 36, 286. https://doi.org/10.1007/s11149-009-9098-Z

Dinger, V., \& Von Hagen, J. (2009). Does Interbank Borrowing Reduce Bank Risk? Journal of Money, Credit and Banking, 41, 491-506.

https://doi.org/10.1111/j.1538-4616.2009.00217.x

Enkhbold, E., \& Otgonshar, B. (2013). The Effect of Deposit Insurance on Risk Taking in Asian Banks. Asian Journal of Finance \& Accounting, 5. https://doi.org/10.5296/ajfa.v5i1.3023

EY Eastern-Africa-Banking-Sector (2013). https://www.scribd.com/document/239787872

Fazelina Sahul, H., \& Norhanishah Mohd, Y. (2017). Market Discipline and Bank Risk Taking: Evidence from the East Asian Banking Sector. East Asian Economic Review, 21, 29-57. https://doi.org/10.11644/KIEP.EAER.2017.21.1.322

Flannery, M. J., \& Sorescu, S. M. (1996). Evidence of Bank Market Discipline in Subordinated Debenture Yields: 1983-1991. The Journal of Finance, 51, 1347-1377.

https://doi.org/10.1111/j.1540-6261.1996.tb04072.x

Fosu, S., Ntim, C. G., Coffie, W., \& Murinde, V. (2017). Bank Opacity and Risk-Taking: Evidence from Analysts' Forecasts. Journal of Financial Stability, 33, 81-95. 
https://doi.org/10.1016/j.jfs.2017.10.009

Fungáčová, Z., Solanko, L., \& Weill, L. (2014). Does Competition Influence the Bank Lending Channel in the Euro Area? Journal of Banking \& Finance, 49, 356-366.

https://doi.org/10.1016/j.jbankfin.2014.06.018

Furfine, C. H. (2001). Banks as Monitors of Other Banks: Evidence from the Overnight Federal Funds Market. The Journal of Business, 74, 33-57.

https://doi.org/10.1086/209662

Galai, D., \& Masulis, R. W. (1976). The Option Pricing Model and the Risk Factor of Stock. Journal of Financial Economics, 3, 53-81. https://doi.org/10.1016/0304-405X(76)90020-9

Galloway, T. M., Lee, W. B., \& Roden, D. M. (1997). Banks' Changing Incentives and Opportunities for Risk Taking. Journal of Banking \& Finance, 21, 509-527. https://doi.org/10.1016/S0378-4266(96)00052-0

Gilbert, R. A. (1990). Market Discipline of Bank Risk: Theory and Evidence. Federal Reserve Bank of St. Louis Review, 72, 3-18. https://doi.org/10.20955/r.72.3-18

Goldberg, L. G., \& Hudgins, S. C. (2002). Depositor Discipline and Changing Strategies for Regulating Thrift Institutions. Journal of Financial Economics, 63, 263-274. https://doi.org/10.1016/S0304-405X(01)00096-4

Gorton, G., \& Santomero, A. M. (1990). Market Discipline and Bank Subordinated Debt: Note. Journal of Money, Credit and Banking, 22, 119-128.

https://doi.org/10.2307/1992132

Goyal, V. K. (2005). Market Discipline of Bank Risk: Evidence from Subordinated Debt Contracts. Journal of Financial Intermediation, 14, 318-350. https://doi.org/10.1016/j.jfi.2004.06.002

Gropp, R., \& Moerman, G. (2004). Measurement of Contagion in Banks' Equity Prices. Journal of International Money and Finance, 23, 405-459.

https://www.ecb.europa.eu//pub/pdf/scpwps/ecbwp297.pdf https://doi.org/10.1016/j.jimonfin.2004.01.005

Gropp, R., \& Vesala, J. (2004). Deposit Insurance, Moral Hazard and Market Monitoring. Review of Finance, 8, 571-602. https://doi.org/10.1007/s10679-004-6280-0

Hadad, M. D., Agusman, A., Monroe, G. S., Gasbarro, D., \& Zumwalt, J. K. (2011). Market Discipline, Financial Crisis and Regulatory Changes: Evidence from Indonesian Banks. Journal of Banking \& Finance, 35, 1552-1562.

https://doi.org/10.1016/j.jbankfin.2010.11.003

Hannan, T. H., \& Hanweck, G. A. (1988). Bank Insolvency Risk and the Market for Large Certificates of Deposit. Journal of Money, Credit and Banking, 20, 203-211.

http://links.jstor.org/sici?sici=0022-2879\%2819880..0.CO\%3B2-5\&origin=bcfulltext(ap plication/pdf) https://doi.org/10.2307/1992111

Haq, M., \& Heaney, R. (2012). Factors Determining European Bank Risk. Journal of International Financial Markets, Institutions and Money, 22, 696-718. https://doi.org/10.1016/j.intfin.2012.04.003

Haq, M., Avkiran, N. K., \& Tarazi, A. (2019). Does Market Discipline Impact Bank Charter Value? The Case for Australia and Canada. Accounting \& Finance, 59, 253-276. https://doi.org/10.1111/acfi.12244

Hoang, K. T., Faff, R., \& Haq, M. (2014). Market Discipline and Bank Risk Taking. Australian Journal of Management, 39, 327-350. https://doi.org/10.1177/0312896213496800 
Jensen, M. C., \& Meckling, W. H. (1976). Theory of the Firm: Managerial Behavior, Agency Costs and Ownership Structure. Journal of Financial Economics, 3, 305-360. https://doi.org/10.1016/0304-405X(76)90026-X

Karas, A. O., Pyle, W., \& Schoors, K. (2019). Deposit Insurance, Market Discipline and Bank Risk. USE Working Paper Series, 19(02).

Karas, A., Pyle, W., \& Schoors, K. (2013). Deposit Insurance, Banking Crises, and Market Discipline: Evidence from a Natural Experiment on Deposit Flows and Rates. Journal of Money, Credit and Banking, 45, 179-200. https://doi.org/10.1111/j.1538-4616.2012.00566.x

Klomp, J., \& de Haan, J. (2012). Banking Risk and Regulation: Does One Size Fit AlR. DNB Working Papers 323, Netherlands Central Bank, Research Department. https://doi.org/10.1016/j.jbankfin.2011.10.006

Koehn, M., \& Santomero, A. M. (1980). Regulation of Bank Capital and Portfolio Risk. The Journal of Finance, 35, 1235-1244. https://doi.org/10.1111/j.1540-6261.1980.tb02206.x

Konishi, M., \& Yasuda, Y. (2004). Factors Affecting Bank Risk Taking: Evidence from Japan. Journal of Banking \& Finance, 28, 215-232. https://doi.org/10.1016/S0378-4266(02)00405-3

Kusairi, S., Sanusi, N. A., \& Ismail, A. G. (2018). Dilemma of Deposit Insurance Policy in ASEAN Countries: Does It Promote Banking Industry Stability or Moral Hazard? Borsa Istanbul Review, 18, 33-40. https://doi.org/10.1016/j.bir.2017.08.006

Kwan, S., \& Eisenbeis, R. A. (1997). Bank Risk, Capitalization, and Operating Efficiency. Journal of Financial Services Research, 12, 117-131. https://doi.org/10.1023/A:1007970618648

Laeven, L., \& Levine, R. (2009). Bank Governance, Regulation and Risk Taking. Journal of Financial Economics, 93, 259-275. https://doi.org/10.1016/j.jfineco.2008.09.003

Lambert, C., Noth, F., \& Schüwer, U. (2017). How Do Insured Deposits Affect Bank Risk? Evidence from the 2008 Emergency Economic Stabilization Act. Journal of Financial Intermediation, 29, 81-102. https://doi.org/10.1016/j.jfi.2015.07.001

Lotto, D. J. (2016). Efficiency of Capital Adequacy Requirements in Reducing Risk-Taking Behavior of Tanzanian Commercial Banks. Research Journal of Finance and Accounting, 21, 110-118.

Martinez Peria, M. S., \& Schmukler, S. L. (2001). Do Depositors Punish Banks for Bad Behavior? Market Discipline, Deposit Insurance, and Banking Crises. The Journal of Finance, 56, 1029-1051. https://doi.org/10.1111/0022-1082.00354

Mbowe, E. R., Mrema, A., \& Shayo, S. (2020). Determinants of Bank Lending Interest Rates in Tanzania. American Journal of Industrial and Business Management, 10, 1206-1236. https://doi.org/10.4236/ajibm.2020.107081

Milne, A. (2002). Bank Capital Regulation as an Incentive Mechanism: Implications for Portfolio Choice. Journal of Banking \& Finance, 26, 1-23. https://doi.org/10.1016/S0378-4266(01)00198-4

Nier, E., \& Baumann, U. (2006). Market Discipline, Disclosure and Moral Hazard in Banking. Journal of Financial Intermediation, 15, 332-361. https://doi.org/10.1016/j.jfi.2006.03.001

Park, S., \& Peristiani, S. (1998). Market Discipline by Thrift Depositors. Journal of Money, Credit and Banking, 30, 347. https://doi.org/10.2307/2601105

Saunders, A., Strock, E., \& Travlos, N. G. (1990). Ownership Structure, Deregulation, and Bank Risk Taking. The Journal of Finance, 45, 643-654. 
https://doi.org/10.1111/j.1540-6261.1990.tb03709.x

Semenova, M. (2012). Market Discipline and Banking System Transparency: Do We Need More Information? Journal of Banking Regulation, 13, 241-248. https://doi.org/10.1057/jbr.2011.21

Sironi, A. (2003). Testing for Market Discipline in the European Banking Industry: Evidence from Subordinated Debt Issues. Journal of Money, Credit, and Banking, 35, 443-472. https://doi.org/10.2139/ssrn.249284

Stiroh, K. J. (2006). New Evidence on the Determinants of Bank Risk. Journal of Financial Services Research, 30, 237-263. https://doi.org/10.1007/s10693-006-0418-5

Tovar-García, E. D. (2015). Market Discipline through Subordinated Debt in Mexican Banks. Revista de Economia Aplicada, 23, 61-80.

Wójcik-Mazur, A., \& Szajt, M. (2015). Determinants of Liquidity Risk in Commercial Banks in the European Union. Argumenta Oeconomica, 2, 25-47.

https://doi.org/10.15611/aoe.2015.2.02

Wooldridge, J. M. (2010). Econometric Analysis of Cross Section and Panel Data. Cambridge, MA: MIT Press.

Wu, Y., \& Bowe, M. (2010). Information Disclosure, Market Discipline and the Management of Bank Capital: Evidence from the Chinese Financial Sector. Journal of Financial Services Research, 38, 159-186. https://doi.org/10.1007/s10693-010-0091-6

Yan, X., Skully, M., Avram, K., \& Vu, T. (2014). Market Discipline and Deposit Guarantee: Evidence from Australian Banks. International Review of Finance, 14, 431-457. https://doi.org/10.1111/irfi.12028

Zhang, Z., Song, W., Sun, X., \& Shi, N. (2014). Subordinated Debt as Instrument of Market Discipline: Risk Sensitivity of Sub-Debt Yield Spreads in UK Banking. Journal of Economics and Business, 73, 1-21. https://doi.org/10.1016/j.jeconbus.2013.11.002 